Matthews, R. E. F. (1953). J. gen. Microbiol. 8, 277-288.

\title{
Chemotherapy and Plant Viruses
}

\author{
By R. E. F. MATTHEWS \\ Plant Diseases Division, Department of Scientific and Industrial Research, \\ Auckland, New Zealand*
}

SUMMARY: When the guanine analogue, 5-amino-7-hydroxy-1-v-triazolo (D) pyrimidine (guanazolo), was sprayed on the leaves of tobacco or Nicotiana glutinosa plants it reduced the number of local lesions and delayed or inhibited systemic spread of lucerne mosaic virus. Guanazolo was more effective when applied before inoculation, but had some effect if applied up to about the second day after inoculation. The compound was more effective in solution in $0.1 \%$ sodium bicarbonate than in aqueous suspension. With mechanically inoculated plants guanazolo watered on the soil around the plants was less effective than when sprayed on the leaves.

Incubated with the virus in vitro the compound did not affect infectivity. In concentrations up to $c .0 \cdot 005 \mathrm{M}$ guanazolo usually caused negligible plant damage, but at higher concentrations produced a slight yellowing and distortion in the younger leaves with general stunting if treatments were prolonged.

The virus-inhibitory activity of guanazolo was reversed by adenine, guanine and possibly by hypoxanthine, but not by xanthine, uric acid, theobromine, theophylline, caffeine, uracil or thymine.

The triazolo analogue of adenine severely damaged plants and had only slight virus inhibitory activity. The hypoxanthine analogue caused no plant damage. It was less effective than guanazolo in tobacco and $N$. glutinosa but more effective in reducing the number of local lesions produced in beans. Thiouracil, methylthiouracil and propylthiouracil were ineffective against lucerne mosaic virus. Thiouracil caused fairly severe plant damage.

Guanazolo had slight or negligible effects on spotted wilt virus in tomato, potato viruses $X$ and $Y$ in potato, and tobacco and pea mosaic virus in peas. Applied as a leaf spray at $0.01 \mathrm{M}$ concentration guanazolo delayed or prevented systemic movement of cucumber mosaic virus from mechanically inoculated cucumber leaves, but had no effect when watered on the soil. However, watering the compound on the soil gave some control when the virus was introduced by aphids.

The indirect measures at present used to control plant-virus diseases, such as eliminating sources of infection and developing resistant varieties, are for many diseases only partially effective. The development of compounds which delay or inhibit virus multiplication within the plant could form a basis for a more widely applicable method of control. A variety of compounds, mainly antibiotics, plant-growth substances and dyestuffs, has been tested for possible antivirus activity. Takahashi (1948), using a detached leaf technique, found that malachite green decreased the amount of tobacco mosaic virus produced in Nicotiana glutinosa leaf tissue. Stoddard (1947) stated that the virus causing $X$ disease of peach could be inactivated in living peach buds by soaking buds in solutions of a variety of compounds, and that trees watered or injected with various compounds could be protected against disease. Limasset, Levieil \& Sechet (1948) found that 2-methyl-4-chlorophenoxy acetic acid temporarily inhibited the development of potato viruses $X$ and $Y$ in tobacco.

\footnotetext{
* Present address: Agricultural Research Council, Plant Virus Research Unit, Molteno Institute, Cambridge.
} 
Locke (1948) found that 2:4-dichlorophenoxyacetic acid masked the symptoms of leaf roll in a Netted Gem potato plant. He considered that the amount of active virus was also reduced. Kutsky \& Rawlins (1950) found that napthalene acetic acid decreased the amount of tobacco mosaic virus in tobacco tissue culture. Manil (1947) and Beale \& Jones (1951) failed to obtain any control of tobacco mosaic virus or potato yellow-dwarf with a range of antibiotics. Ryjkoff \& Smirnova (1948) showed that the multiplication of tobacco mosaic virus was depressed when inoculated leaves of $N$. glutinosa were immersed in $0.1 \%$ magnesium sulphate solution or when tobacco leaves were infiltrated with $0.05 \%$ trypaflavine solution. Thomas \& Baker (1949), working with a mosaic disease in carnations, stated that virus activity was reduced when plants were treated with several compounds, including a number of sulphonamides. Köhler \& Hauschild (1950) found that sodium sulphide, potassium hydroxide, potassium permanganate, and ascorbic acid had no effect on potato leaf roll. Nickell, Greenfield \& Burkholder (1950) described the effects of various nucleic acid components and related compounds on virus tumours in Rumex, and Nickell (1951) showed that methylene blue, crystal violet and malachite green inhibited the growth of these tumours. Commoner \& Mercer (1951) found that thiouracil inhibited multiplication of tobacco mosaic virus in tobacco leaf tissue.

It is usually assumed and has been shown for one plant virus (Markham \& Smith, K. M. 1949) that the nucleic acid of the virus nucleoprotein is necessary for infectivity. In considering the possibility that analogues of the nucleic acid bases might be effective against plant viruses, our attention was drawn to the work of Kidder, Dewey, Parks \& Woodside (1949) on the effects of guanazolo and other substituted purines on the metabolism of Tetrahymena and on the development of malignant cells in mice. The present paper describes tests with a number of these substituted purines and three analogues of uracil against several plant viruses. Preliminary reports of some of these results have already appeared (Matthews, 1951, 1952).

\section{MATERIALS AND METHODS}

Plants were grown in 4 in. pots in the glasshouse in a steam-disinfected potting mixture containing approximately $57 \%$ loam, $33 \%$ rotted organic matter and $10 \%$ coarse sand. Lucerne mosaic virus was obtained from white clover (Fry, 1953); cucumber mosaic virus from a field infected tomato plant. The plants used were Nicotiana glutinosa, N. tabacum var. White Burley, Phaseolus vulgaris var. Sydney Wonder, Trifolium subterraneum var. Tallarook and the Short Prickly variety of cucumber. In Nicotiana glutinosa and N. tabacum lucerne mosaic virus produces etched ringspot (Pl. 1, fig. 1) or solid necrotic local lesions after 3-6 days, followed by systemic vein-clearing and etched mottling with some necrosis. In $N$. glutinosa it distorts leaves and stunts growth, particularly in the early stages of systemic spread (Pl. 1, fig. 2). In beans the virus produces brown necrotic local lesions. In the variety of subterranean clover used the virus produces a severe disease leading to death of the plants. 
$N$. glutinosa plants were inoculated when $c$. 2-3 in. high with 3-4 expanded leaves; tobacco when it had two or three fairly well-expanded leaves and beans when the primary pair of leaves was fully developed. In each experiment plants were selected for uniformity of size and appearance. In placing plants in groups for treatments most of the remaining variation in size was kept within treatments. In all mechanical inoculations fine-grade carborundum powder was sprinkled on the leaves before inoculation. Unless otherwise noted dilutions of infective sap were made in distilled water and leaves were not washed after inoculation.

\section{Compounds}

5-amino-7-hydroxy-1-v-triazolo (D) pyrimidine (Guanazolo),

7-hydroxy-1-v-triazolo (D) pyrimidine (hypoxanthine analogue),

7-amino-1-v-triazolo (D) pyrimidine (adenine analogue),

5-hydroxy-7-amino-1-v-triazolo (D) pyrimidine,

5:7-dihydroxy-1-v-triazolo (D) pyrimidine,

2-hydroxy-6-aminopurine,

5-amino-7-hydroxy-(3, 1, 2)-oxadiazolo- $(5,4 d)$ pyrimidine,

2:6-diaminopurine

(all given by the American Cyanamid Company);

2-aza adenine (given by Merck and Co.),

thiouracil, 6-methylthiouracil and propylthiouracil (Fisher Scientific

Company),

adenine, guanine, thymine, uracil, hypoxanthine, caffeine, xanthine and theophylline (Light and Co.),

and uric acid and theobromine (British Drug Houses Ltd.).

Purity of compounds. The purity of the compounds used in reversal experiments was tested by paper chromatography. Two solvents were used-that of Marshak \& Vogel (1951) and that of Markham \& Smith, J. D. (1949). Reflex prints with no. 50 document paper were made of chromatograms under ultraviolet light with a Hanovia lamp and a filter as described by Markham \& Smith, J. D. (1949).

Adenine and guanine could be adequately separated by the tertiary butanol system. The first batch of commercial guanine used in reversal experiments was shown to contain about $23 \%$ (determined by elution from chromatogram and estimation in a Beckman spectrophotometer) of a compound moving with the same Rf. as adenine. A second batch used in later experiments showed no evidence of such impurity. Resolution of hypoxanthine and adenine was not obtained with either solvent. However, since this work was completed the adenine and hypoxanthine samples used have been examined by the paper electrophoresis technique of Markham \& Smith (1951). While the adenine had no detectable impurities, the hypoxanthine preparation was shown to contain more than $50 \%$ of adenine.

Treatments. Water-soluble compounds were applied in aqueous solution. Other compounds were applied as a suspension in water or were brought into solution by heating below $100^{\circ}$ in 0.1 and $0.3 \% \mathrm{NaHCO}_{3}$ or in dilute hydro- 
chloric acid solution. (In Matthews 1951 the concentration of $\mathrm{NaHCO}_{3}$ was incorrectly stated to be $1.0 \%$ instead of $0.1 \%$.) All percentages of solids in solution are given on a $\mathrm{w} / \mathrm{v}$ basis. In some experiments compounds were watered on the soil around the base of the plant, but in the majority they were sprayed evenly over the surface of all leaves, using a small hand atomizer.

Measurement of activity of compounds. Activity of compounds was assayed by counts of local lesions, by the number of plants developing systemic symptoms, and by the mean number of days taken to develop systemic symptoms. In most experiments 6-12 plants were used for each treatment. The plants showing systemic symptoms were counted daily; counts made more frequently would increase the subjective error involved in determining when a plant first shows symptoms. Experiments were usually carried on for several weeks until the plants became mature or pot bound. Daily observations of the number of systemically infected plants provided grouped data where the group interval was rather large in relation to the mean (at least for untreated plants). For this reason uniformity trials have so far failed to yield useful information on the form of the distribution of time taken for systemic symptoms to develop. Thus no test for the significance of differences in the data on systemic infections can be made at present. To give an indication of the variation, in a uniformity trial in which fifteen groups of six untreated plants were inoculated with lucerne mosaic virus at dilutions from $1 / 1$ to $1 / 10,000$, the mean number of days for systemic symptoms to appear in groups of six plants varied from $\mathbf{5 \cdot 8}$ to $\mathbf{9 \cdot 0}$.

\section{RESULTS}

\section{Lucerne mosaic virus}

Of the nine substituted purines tested only the triazolopyrimidine analogues of guanine, adenine and hypoxanthine had any effect on the development of lucerne mosaic virus infections. Table 1 summarizes a comparative test with these three compounds. Guanazolo was the most effective, except in beans, where only the hypoxanthine analogue reduced the number of local lesions. However, guanazolo at $0.01 \mathrm{~m}$ caused a marked reduction in the size of the local lesions in beans compared with controls or the other treatments. In tobacco and $N$. glutinosa the adenine analogue at $0.01 \mathrm{~m}$ caused general stunting involving a virtual cessation of growth in the youngest apical leaves, accompanied by yellowing and some distortion and down-curling of leaves with some necrosis. Such damage began to appear 2-3 days after the first treatment, and plants took several weeks to regain normal growth after treatments ceased. The hypoxanthine analogue had no visible effect on plant growth. At $0.02 \mathrm{M}$ guanazolo caused fairly marked stunting of plants and slight yellowing of leaves in $N$. glutinosa and tobacco. At $0.01 \mathrm{~m}$ this effect was much less severe, and below $0.005 \mathrm{~m}$ there was usually no detectable effect on growth. When growing conditions were good the damage produced by guanazolo up to about $0.01 \mathrm{~m}$ disappeared after a few days. Pl. 1, fig. 3, 
illustrates the effect of the three analogues on growth of $N$.glutinosa. In bean plants guanazolo caused more severe yellowing and stunting.

Table 1. Effect of guanine, adenine and hypoxanthine analogues on lucerne mosaic virus in Nicotiana glutinosa, tobacco and beans

\begin{tabular}{|c|c|c|c|c|c|c|}
\hline \multicolumn{3}{|c|}{ In tobacco } & \multicolumn{3}{|c|}{ In $N \cdot$ glutinosa } & In beans \\
\hline & & $\begin{array}{l}\text { Mean no. } \\
\text { of days for }\end{array}$ & & & $\begin{array}{l}\text { Mean no. } \\
\text { of days for }\end{array}$ & \\
\hline $\begin{array}{l}\text { No. of } \\
\text { local } \\
\text { lesions, } \\
\text { (mean of }\end{array}$ & $\begin{array}{l}\text { No. of plants } \\
\text { out of } 6 \\
\text { systemically } \\
\text { infected }\end{array}$ & $\begin{array}{l}\text { systemically- } \\
\text { infected } \\
\text { plants } \\
\text { to show }\end{array}$ & $\begin{array}{l}\text { No. of } \\
\text { local } \\
\text { lesions, } \\
\text { (mean of }\end{array}$ & $\begin{array}{l}\text { No. of plants } \\
\text { out of } 6 \\
\text { systemically- } \\
\text { infected }\end{array}$ & $\begin{array}{l}\text { systemically- } \\
\text { infected } \\
\text { plants } \\
\text { to show }\end{array}$ & $\begin{array}{l}\text { No. of } \\
\text { local } \\
\text { lesions, } \\
\text { (mean of }\end{array}$ \\
\hline
\end{tabular}

Treatment 12 leaves) after 25 days symptoms 18 leaves) after 25 days symptoms 24 leaves)

\begin{tabular}{|c|c|c|c|c|c|c|c|}
\hline Control A & 174 & 6 & $5 \cdot 0$ & $17 \cdot 0$ & $\mathbf{5}$ & $7 \cdot 2$ & 68 \\
\hline Control B & 138 & 6 & $5 \cdot 3$ & $16 \cdot 5$ & 5 & $8 \cdot 1$ & 142 \\
\hline Control C & 132 & 6 & $5 \cdot 0$ & $9 \cdot 7$ & 4 & $14 \cdot 2$ & 157 \\
\hline \multicolumn{8}{|c|}{ Guanazolo } \\
\hline $0.01 \mathrm{M}$ & $2 \cdot 4$ & $\mathbf{0}$ & - & $0 \cdot 28$ & 0 & - & 113 \\
\hline $0 \cdot 003 \mathrm{M}$ & $5 \cdot 6$ & 2 & $14 \cdot 5$ & $0 \cdot 56$ & $\mathbf{0}$ & - & 135 \\
\hline $0.001 \mathrm{M}$ & $13 \cdot 6$ & 6 & $10 \cdot 3$ & $4 \cdot 0$ & 1 & 17 & 94 \\
\hline $0 \cdot 0003 \mathrm{M}$ & 88 & 6 & $6 \cdot 5$ & $\mathbf{3} \cdot \mathbf{3}$ & 2 & $13 \cdot 5$ & 110 \\
\hline $0 \cdot 0001 \mathrm{M}$ & 159 & 6 & $5 \cdot 5$ & $15 \cdot 5$ & 4 & $12 \cdot 7$ & 89 \\
\hline \multicolumn{8}{|c|}{ Hypoxanthine analogue } \\
\hline $0.01 \mathrm{M}$ & 70 & 6 & $6 \cdot 0$ & $7 \cdot 4$ & 2 & $9 \cdot 5$ & $18 \cdot 5$ \\
\hline $0.003 \mathrm{M}$ & 37 & 6 & $6 \cdot 3$ & $8 \cdot 3$ & 4 & $8 \cdot 5$ & 73 \\
\hline $0.001 \mathrm{M}$ & 31 & 6 & $6 \cdot 2$ & $7 \cdot 9$ & 5 & $10 \cdot 4$ & 137 \\
\hline $0 \cdot 0003 \mathrm{M}$ & 91 & 6 & $5 \cdot 3$ & $14 \cdot 7$ & $\mathbf{5}$ & $9 \cdot 6$ & 160 \\
\hline $0 \cdot 0001 \mathrm{M}$ & 115 & 6 & $5 \cdot 2$ & $16 \cdot 1$ & 5 & $8 \cdot 4$ & 142 \\
\hline \multicolumn{8}{|c|}{ Adenine analogue } \\
\hline $0.01 \mathrm{M}$ & 一 & o & 一 & - & $\mathbf{5}$ & $13 \cdot 6$ & 一 \\
\hline $0.003 \mathrm{M}$ & $\mathbf{3 \cdot 2}$ & 6 & $10 \cdot 7$ & $\mathbf{3} \cdot \mathbf{3}$ & 6 & $8 \cdot 8$ & 89 \\
\hline $0.001 \mathrm{M}$ & 11 & 6 & $8 \cdot 2$ & $8 \cdot 1$ & 6 & $8 \cdot 8$ & 120 \\
\hline $0.0003 \mathrm{M}$ & 48 & 6 & $5 \cdot 3$ & $11 \cdot 0$ & 6 & $8 \cdot 3$ & 75 \\
\hline $0.0001 \mathrm{M}$ & 122 & 6 & $5 \cdot 3$ & $18 \cdot 5$ & 5 & $7 \cdot 8$ & 150 \\
\hline
\end{tabular}

Compounds. Guanazolo and the adenine analogue at $0.01 \mathrm{~m}$ were in solution in $0.1 \% \mathrm{NaHCO}_{3}$, the other concentrations being prepared by dilution from this. Hypoxanthine analogue was in solution in water.

Times of treatment. Two sprays in the week before and two in the week after inoculation.

Source of inoculum. Sap from infected tobacco diluted 1/100 for $N$. glutinosa and tobacco and $1 / 30$ for beans.

Plant damage. Adenine analogue at $0.01 \mathrm{~m}$ caused considerable necrotic damage on inoculated leaves and marked general stunting. Accurate local lesion counts were not possible at this concentration.

At concentrations producing damage inoculation of several leaves after spray treatments increased the damage effects in non-inoculated leaves. This suggests that the wounding produced by carborundum inoculation allows a greater amount of the compound to enter the plant. To test whether guanazolo masked symptoms or prevented systemic movement of active virus, inoculation tests were made after several weeks from the symptomless treated plants in a number of experiments. In all cases local lesions were produced in tobacco only from plants showing systemic symptoms. In some experiments systemic symptoms were less severe in treated plants than in untreated, 
and acute early necrosis was absent. However, in one case a test for relative concentration of virus (measured by the number of local lesions produced in tobacco at three dilutions) showed no significant difference between treated and untreated systemically infected plants 30 days after inoculation. In one experiment none of six plants sprayed before and after inoculation developed any local or systemic symptoms; some inoculated leaves showed a few indefinite yellowish areas. Twenty-one days after inoculation tests for the presence of active virus in these six plants were made by inoculation to tobacco. For each plant, inoculations were made from young leaves and from inoculated leaves. Virus could not be detected in any of the young leaves, but the tests from inoculated leaves produced local lesions in three of the six plants. Since the viability in vitro of lucerne mosaic virus is about 2-3 days, it is unlikely that these lesions were caused by virus in the initial inoculum remaining on the surface of the leaf. It appears that the virus had multiplied locally to a limited extent without producing definite local lesions and without becoming systemic.

In most experiments guanazolo treatments considerably decreased the number of local lesions. In some the lesions produced in treated plants were all of the same type as those of the controls (i.e. etched rings or solid necrotic spots or a mixture of these types). In other experiments a variable proportion of the local lesions produced in treated plants were much less necrotic than in the controls and graded into vague yellowish spots, which were usually few compared with necrotic or etched lesions. In counting local lesions all lesions which showed any degree of etching or necrosis were included. In addition to decreasing the number of visible local lesions, guanazolo sometimes delayed their appearance for several days.

Guanazolo was more effective in solution in $\mathrm{NaHCO}_{3}$ than in suspension, and was usually more effective when applied before inoculation than after inoculation. It was ineffective if applied more than 1-2 days after inoculation (Table 2). In general, guanzolo was more effective with more dilute inoculum. Leaf spraying was more effective than watering on the soil, at least when the virus is introduced by mechanical means (Table 3). PI. 1, figs. 1 and 2, illustrate the effect of guanazolo treatment on lucerne mosaic infections.

Satisfactory levels of infections in control plants were not obtained when lucerne mosaic virus was transmitted to $N$. glutinosa and tobacco by aphids. However, in one experiment, using subterranean clover, spraying with guanazolo was ineffective against aphid-transmitted virus; there was a suggestion that watering with the compound may have had some effect.

In a number of experiments in which infective sap was incubated with 1.0 and $0.1 \%$ guanazolo in suspension or in solution in $\mathrm{NaHCO}_{3}$ for $2 \mathrm{hr}$., and in which the leaves of test tobacco plants were either washed or left unwashed after inoculation, a significant effect on numbers of local lesions was not found. In these experiments the amount of guanazolo entering the leaf from the inoculum must have been insufficient to affect the number of local lesions.

A number of naturally occurring purines and two pyrimidines were tested 
for ability to reverse the virus inhibitory activity of guanazolo. In such tests plants received two sprays with guanazolo and two sprays with the compound under test in the 4 days before inoculation, followed by two or three treatments with the test compound in the week after inoculation. The adenine, guanine and hypoxanthine preparations used annulled the activity

Table 2. Effect of interval between treatment with guanazolo and time of inoculation. Lucerne mosaic virus in tobacco

Days of treatments
in relation to day
of inoculation
(day 0 )
Untreated
control
$-7,-6$
$-6,-5$
$-5,-4$
$-4,-3$
$-3,-2$
$-2,-1$
$-1,0$
0,1
1,2
2,3
$\mathbf{3}, 4$
$\mathbf{4 , 5}$
$\mathbf{5 , 6}$
$\mathbf{6 , 7}$
$\mathbf{7 , 8}$

\begin{tabular}{ccc}
$\begin{array}{c}\text { No. of local } \\
\text { lesions, mean } \\
\text { of } 12 \text { leaves }\end{array}$ & $\begin{array}{c}\text { No. of plants } \\
\text { infected out } \\
\text { of } 6 \text { after } \\
18 \text { days }\end{array}$ & $\begin{array}{c}\text { Mean no. of days } \\
\text { for systemically } \\
\text { infected plants to } \\
\text { show symptoms }\end{array}$ \\
166 & 6 & $7 \cdot 3$ \\
49 & & \\
45 & 5 & $12 \cdot 0$ \\
44 & 5 & $13 \cdot 2$ \\
38 & 5 & $13 \cdot 4$ \\
44 & 4 & $14 \cdot 2$ \\
34 & 4 & $12 \cdot 7$ \\
34 & 6 & $14 \cdot 5$ \\
57 & 2 & $10 \cdot 0$ \\
71 & 2 & $14 \cdot 5$ \\
139 & 5 & $10 \cdot 6$ \\
145 & 5 & $8 \cdot 8$ \\
94 & 6 & $9 \cdot 5$ \\
202 & 6 & $7 \cdot 5$ \\
181 & 6 & $7 \cdot 0$ \\
178 & 6 & $7 \cdot 5$ \\
\hline
\end{tabular}

Compound. Guanazolo $0 \cdot 1 \%$ in solution in $0 \cdot 1 \% \mathrm{NaHCO}_{3}(0 \cdot 1 \% \bumpeq 0.007 \mathrm{M})$.

Times of treatment. One spray on each of two consecutive days as noted in table. Source of inoculum. Sap from infected $N$. glutinosa diluted 1/5.

of guanazolo, and xanthine, uric acid, theobromine, theophylline, caffeine, uracil and thymine had no effect. Guanine applied in aqueous suspension had no annulling activity, but had when applied as $0.1 \%$ or $0.01 \mathrm{M}$ solution in dilute hydrochloric acid. However, a valid comparison cannot be made between guanine and the other active compounds because of the plant damage produced by the acid solution. Table 4 summarizes a reversal experiment with adenine. The hypoxanthine preparation (which was later shown to contain between 50 and $60 \%$ of adenine) was more effective than adenine in annulling the activity of guanazolo. In some experiments this mixture increased the number of local lesions and rate of systemic spread above that of unsprayed controls. In view of this greater activity it is possible that hypoxanthine itself has some annulling activity.

Of the three uracil analogues, tested at $0.01 \mathrm{~m}$, only thiouracil had any effect. This compound caused marked yellowing of young leaves, curling down of leaf margins and virtual cessation of apical growth in $N$. glutinosa and tobacco (Pl. 1, fig. 4). This damage may well account, at least in part, for the slight delay which occurred in the development of systemic symptoms of lucerne mosaic. 
Table 3. Application of guanazolo by watering on soil and spraying on leaves. Effect on lucerne mosaic virus in Nicotiana glutinosa

Time of treatment

Before inoculation

After inoculation

Before and after inoculation

Before inoculation

After inoculation

Before and after inoculation
Method of treatment Inoculum at $1 / 1$

Control untreated

Sprayed

Watered

Sprayed and watered

Sprayed

Watered

Sprayed and watered

Sprayed

Watered

Sprayed and watered

Inoculum at $1 / 10$

Control untreated

Sprayed

Watered

Sprayed and watered

Sprayed

Watered

Sprayed and watered

Sprayed

Watered

Sprayed and watered

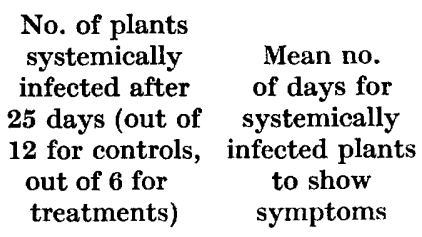

$\begin{array}{rr}10 & 6 \cdot 0 \\ 1 & 12 \cdot 0 \\ 5 & 7 \cdot 0 \\ 0 & - \\ 4 & 9 \cdot 5 \\ 6 & 9 \cdot 2 \\ 5 & 11 \cdot 2 \\ 0 & - \\ 5 & 9 \cdot 8 \\ 0 & - \\ & \\ 10 & 7 \cdot 6 \\ 0 & - \\ 3 & 8 \cdot 3 \\ 0 & - \\ 0 & - \\ 5 & 9 \cdot 8 \\ 2 & 12 \cdot 5 \\ 0 & - \\ 1 & 21 \cdot 0 \\ 0 & -\end{array}$

Compound. Guanazolo 0.1\% in solution in $0 \cdot 1 \% \mathrm{NaHCO}_{3}$.

Times of treatment. Before inoculation; two treatments, one on each of the two days before inoculation. After inoculation; five treatments at the rate of three per week beginning the day after inoculation. Before and after inoculation; a combination of the above.

Source of inoculum. Infected N. glutinosa.

Table 4. Effect of varying concentrations of adenine on the inhibitory activity of guanazolo. Lucerne mosaic in Nicotiana glutinosa

\begin{tabular}{|c|c|c|}
\hline $\begin{array}{l}\text { No. of local } \\
\text { lesions (mean } \\
\text { of } 24 \text { leaves) }\end{array}$ & $\begin{array}{c}\text { No. of plants } \\
\text { out of } 6 \\
\text { systemically } \\
\text { infected after } \\
\mathbf{2 4} \text { days }\end{array}$ & $\begin{array}{l}\text { Mean no. of } \\
\text { days for plants } \\
\text { systemically } \\
\text { infected to } \\
\text { show symptoms }\end{array}$ \\
\hline 10 & 6 & $8 \cdot 8$ \\
\hline $2 \cdot 6$ & 0 & - \\
\hline 5.2 & 6 & $8 \cdot 8$ \\
\hline $2 \cdot 7$ & 3 & 11.7 \\
\hline $5 \cdot 4$ & 5 & $9 \cdot 8$ \\
\hline 5.3 & 5 & $11 \cdot 6$ \\
\hline $4 \cdot 2$ & 2 & 14.0 \\
\hline $3 \cdot 3$ & $\overline{1}$ & 11.0 \\
\hline
\end{tabular}

Control

Guanazolo

Adenine $0 \cdot 05 \mathrm{M}$

Adenine $0 \cdot 05 \mathrm{M}+$ guanazolo

Adenine 0.015 $\mathrm{m}+$ guanazolo

Adenine $0.005 \mathrm{M}+$ guanazolo

Adenine $0.0015 \mathrm{M}+$ guanazolo

Adenine 0.0005 $\mathrm{M}+$ guanazolo
No. of plants fected after

Compounds. Guanazolo; $0.005 \mathrm{M}$ in solution in $0.1 \% \mathrm{NaHCO}_{3}$. Adenine; in solution in water.

Times of treatment. Guanazolo on the 4th and 2nd days before inoculation. Adenine on the 3rd and 1st days before, and 3 days in the week after inoculation.

Source of inoculum. Sap from infected $N$. glutinosa diluted $1 / 2$. 


\section{Other viruses}

The substituted purines tested against lucerne mosaic virus had slight or negligible effects on spotted wilt virus in tomato, potato viruses $X$ and $Y$ in potato and tobacco and pea mosaic virus in peas $(2$-aza adenine and the uracil analogues were not tested against these viruses). However, with cucumber mosaic virus more encouraging results have been obtained.

Of nine substituted purines and three analogues of uracil tested guanazolo was the only compound which substantially inhibited the systemic development of cucumber mosaic virus in cucumbers. Treatment with the adenine analogue at $0.01 \mathrm{~m}$ caused marked stunting, yellowing and some distortion of leaves. New young growth began to appear 7-14 days after treatments. 2:6-diaminopurine caused almost complete cessation of growth, plants becoming very dark green and remaining almost the same size for many weeks after treatments stopped. Plants treated with thiouracil became stunted and yellowed after a few days. The delaying effects produced by $2: 6$-diaminopurine and the adenine analogue on the appearance of virus symptoms were probably due, at least in part, to the marked effects these compounds had on plant growth. Treatments with $0.02 \mathrm{M}$-guanazolo caused slight stunting, but in about a week plants grew away from this and made as good growth as untreated controls.

When the cucumber mosaic virus was introduced by mechanical inoculation, guanazolo sprayed on the leaves gave complete or almost complete control, but had no effect when watered on the soil. When the virus was introduced by Myzus persicae in controlled feeding experiments the compound appeared to have some effect when sprayed on the leaves or watered on the soil.

In other experiments treated and untreated cucumber plants, grown in seedling boxes, were exposed to infection by winged aphids. Boxes of plants were placed in randomized positions a short distance from a group of infected cucumber plants on which winged aphids were placed. In an experiment in which Hyperomyzus lactucae was the main aphid employed 69/95 control plants were infected after 48 days while $13 / 51$ plants sprayed with $0.01 \mathrm{~m}$ guanazolo and 4/42 plants watered with guanazolo were infected. However, in another experiment in which large numbers of winged Myzus persicae were employed guanazolo had a much smaller effect (44/47 infected controls; $33 / 48$ infections in plants watered with $0.01 \mathrm{M}$-guanazolo).

\section{DISCUSSION}

As methods for application of compounds, leaf spraying and soil watering have the following advantages over the detached leaf, leaf impregnation and tissue culture methods used by previous workers: (i) they are simple to operate; (ii) plant damage can be readily assessed; (iii) any successful results can be immediately tested on a field scale by the same methods; (iv) there is a minimum of interference with the whole growing plant. Disadvantages are: (i) comparatively large amounts of compounds are required for adequate testing; (ii) little is known about the absorption of compounds through leaves 
or roots; (iii) accurate control of conditions such as temperature and light is difficult.

The experiments described above show that guanazolo can inhibit the systemic invasion by lucerne mosaic virus of tobacco and Nicotiana glutinosa. That this inhibition occurs within the plant and is not merely an inactivation of the virus on the leaf surface is shown by the following: (i) the compound had some effect when watered on the soil; (ii) incubation of the virus in infective sap failed to cause any detectable decrease in infectivity of the virus; (iii) applications of the compound beginning $24 \mathrm{hr}$. after inoculation had some effect.

It seems likely that the compound has most or all of its effect in the inoculated leaves. In actively growing plants in which the virus became established systemically the compound did not prevent full systemic spread of the virus. The results of inoculation tests from young leaves of symptomless plants did not give any evidence that guanazolo masks systemic symptoms. For control of virus diseases it would usually not matter if a plant became infected at the point of entry, so long as the virus did not become systemic. For this reason, and because of the dubious value of local lesion counts as a quantitative measure, in judging the activities of compounds most weight has been placed on the effects on the systemic development of the virus.

Guanazolo probably has at least three effects in inoculated leaves. First, where all the local lesions in treated and untreated plants were of the same necrotic type, there was almost certainly a decrease in the number of successful entry points. Secondly, the delay in the appearance of local lesions (even of the necrotic type) suggests a delay in multiplication of virus. Thirdly, there was a variable degree of masking of local lesions; for example, it was shown once that the virus had entered and multiplied locally in tobacco without producing any typical lesions.

Why the virus should infect and multiply locally in treated plants without subsequently becoming systemic is not clear. The fewer successful entry points in an inoculated leaf the more slowly the virus will move systemically. However, this effect is small compared with that produced by guanazolo. Guanazolo might delay the multiplication of virus inoculated into a cell, without necessarily limiting the final amount produced. This delay would probably mean a longer period before neighbouring cells became infected, and in these cells multiplication might again be delayed. Cell-by-cell movement of virus in the inoculated leaf might be delayed sufficiently for natural senescent changes in the leaf to occur and prevent systemic movement of the virus.

When sprayed on leaves guanazolo is probably most concentrated in the superficial cells of the inoculated leaf where mechanical damage allows increased amounts of the compound to enter. When virus does move out of the inoculated leaf, particles will be transported to cells in many parts of the plant where the compound is too dilute to be effective.

With mechanically transmitted cucumber mosaic virus spraying with 0.01 M-guanazolo gave complete or almost complete control with negligible effects on plant growth. Watering had no effect on development of infection 
in mechanically inoculated plants, but had some effect when the virus was introduced by aphids. When the compound is absorbed through the roots it is probably in highest concentration in the vascular tissue at least for a time. This effect may account for the activity of watered guanazolo when the virus is transmitted by aphids.

Guanazolo inhibits growth of a variety of biological systems. Thus Roblin, Lampen, English, Cole \& Vaughan (1945) found that the triazolo analogues of guanine, adenine and hypoxanthine inhibited growth of Bacterium coli and Staphylococcus aureus. Kidder \& Dewey (1949) found guanazolo to be a potent inhibitor of growth of the micro-organism Tetrahymena geleii, and Kidder et al. (1949) found it inhibited the growth of malignant cells in mice. Growth inhibition by guanazolo has also been shown for virus tumours in Rumex (Nickell et al. 1950), for fungi (Fries \& Panders, 1951) and for algae (Arnow, Sampath, Oleson \& Williams, 1952).

For a number of the above systems it has been suggested that guanazolo interferes with the incorporation of guanine into nucleic acids. Similarly; the evidence so far obtained with lucerne mosaic virus suggests that guanazolo may act by blocking reactions involved in the incorporation of guanine and perhaps adenine into the virus nucleic acids.

I wish to thank Mr G. C. Ward, Applied Mathematics Laboratory, Department of Scientific and Industrial Research, for the statistical analyses, Mr S. A. Rumsey for the photographs in Pl. 1, the Lederle Laboratories Division, American Cyanamid Co. for supplies of the triazolo pyrimidines, and Merck and Co. for a sample of 2-aza adenine.

\section{REFERENCES}

Arnow, P., Sampath, A. C., Oleson, J. J. \& Williams, J. H. (1952). The effect of triazolo pyrimidine analogues on the growth of Stichococcus subtilis. Amer. J. Bot. 39, 151.

Beale, H. P. \& Jones, C. R. (1951). Virus diseases of tobacco mosaic and potato yellow dwarf not controlled by certain purified antibiotics. Contr. Boyce Thompson Inst. 16, (8), 395.

Commoner, B. \& Mercer, F. (1951). Inhibition of the biosynthesis of tobacco mosaic virus by thiouracil. Nature, Lond. 168, 113.

Fries, N. \& Panders, A. (1951). The growth inhibiting effect of 5-amino-7-hydroxytriazolo pyrimidine in fungi and its reversal by purines. Ark. Bot. 2nd Ser. 1, 5, 437. Abstr. in Rev. appl. Mycol. 30, 339.

FrY, P. R. (1953). The occurrence of lucerne mosaic virus in New Zealand. N.Z. J. Sci. Tech. (in the Press).

Kidder, G. W. \& Dewey, V. C. (1949). The biological activity of substituted purines. J. biol. Chem. 179, 181.

Kidder, G. W., Dewey, V. C., Parks, Jun., R. E. \& Woodside, G. L. (1949). Purine metabolism in Tetrahymena and its relation to malignant cells in mice. Science, 109, 511.

KöHLER, E. \& HaUsChiLd, I. (1950). Versuche zur Beeinflussung blattrollkranker Kartoffelknollen durch Chemikalien. NachrBl. dtsch. PflSchDienst, Stuttgart, 2, 24. Abstr. in Rev. appl. Mycol. 30, 186.

KuTsky, R. J. \& Rawlins, T. E. (1950). Inhibition of virus multiplication by naphthalene acetic acid in tobacco tissue cultures as revealed by a spectrophotometric method. J. Bact. 60, 763. 
Limasset, P., Levieil, F. \& Sechet, M. (1948). Influence d'une phytohormone de synthèse sur le développement des virus $\mathrm{X}$ et $\mathrm{Y}$ de la pomme de terre chez le tabac. C.R. Acad. Sci., Paris, 227, 643. Abstr. in Rev. appl. Mycol. 28, 35.

Locke, S. B. (1948). Studies on the chemotherapy of potato virus diseases. Phytopathology, 38, 916.

Manil, P. (1947). Action négative, sur le virus de la mosaique du tabac, de la pénicilline et du prontosil. Ann. Inst. Pasteur, 73, 294.

Markham, R. \& Smith, J. D. (1949). Chromatography of nucleic acid derivatives. Nature, Lond. 163, 250.

Markham, R. \& Smith, K. M. (1949). Studies on the virus of turnip yellow mosaic. Parasitology, 39, 330.

Markham, R. \& Smith, J. D. (1951). Structure of Ribonucleic acid. Nature, Lond. $168,406$.

MARShAK, A. \& VogeL, H. J. (1951). Microdetermination of purines and pyrimidines in biological materials. J. biol. Chem. 189, 597.

MatThEws, R. E. F. (1951). Effect of some substituted purines on the development of plant virus infections. Nature, Lond. 167, 892.

Matthews, R. E. F. (1952). Effect of purines on the multiplication of plant viruses. Nature, Lond. 169, 500.

Nickell, L. G. (1951). Effect of certain dyes on the growth in vitro of virus tumor tissue from Rumex acetosa. Bot. Gaz. 112, 290.

Nickeld, L. G., Greenfield, P. \& Burkholder, P. R. (1950). Atypical growth of plants. III. Growth responses of virus tumors of Rumex to certain nucleic acid components and related compounds. Bot. Gaz. 112, 42.

Roblin, Jr., R. O., Lampen, J. O., English, J. P., Cole, Q. P. \& V aughan, Jr., J.R.(1945). Studies in chemotherapy. VIII. Methionine and purine antagonists and their relation to the sulphonamides. J. Amer. chem. Soc. 67, 290.

RyjкоFF, V. L. \& Smirnova, V. A. (1948). The effect of magnesium ions and acridine preparations on the accumulation of virus proteins in plants affected with tobacco mosaic virus. Microbiology, Moscow, 17 (3), pp. 267. Abstr. in Rev. appl. Mycol. 28, 549.

StodDard, E. M. (1947). The $\mathrm{X}$ disease of peach and its chemotherapy. Bull. Conn. agric. Exp. Sta. no. 506.

TakahashI, W. N. (1948). The inhibition of virus increase by malachite green. Science, 107, 226.

Thomas, W. D. \& Baker, R. R. (1949). Chemical inactivation of the carnation mosaic in vivo. J. Colo.-Wyo. Acad. Sci. 4, 51. Abstr. in Rev. appl. Mycol. 29, 563.

\section{EXPLANATION OF PLATE}

Fig. 1. Effect of guanazolo on the production of local lesions by lucerne mosaic virus in tobacco. Left: control untreated. Right: sprayed $0.1 \%$ guanazolo in solution, treatments commencing the day after inoculation.

Fig. 2. Effect of guanazolo on systemic development of lucerne mosaic virus in Nicotiana glutinosa. Right: untreated control. Left: treated, two sprays $0.1 \%$ guanazolo in solution before inoculation.

Fig. 3. Effect of compounds on growth of $N$. glutinosa. Compounds at $0.01 \mathrm{~m}$ in solution. Two spray treatments. Plants inoculated but no virus symptoms yet developed. From left to right: (i) control unsprayed, (ii) hypoxanthine analogue, (iii) guanazolo, (iv) adenine analogue.

Fig. 4. Effect of compounds on growth of tobacco plants. Uninoculated plants. Compounds at $0.01 \mathrm{M}$ in solution. From left to right: (i) unsprayed control, (ii) guanazolo, (iii) thiouracil, (iv) methylthiouracil. 
Journal of General Microbiology, Vol. 8, No. 2

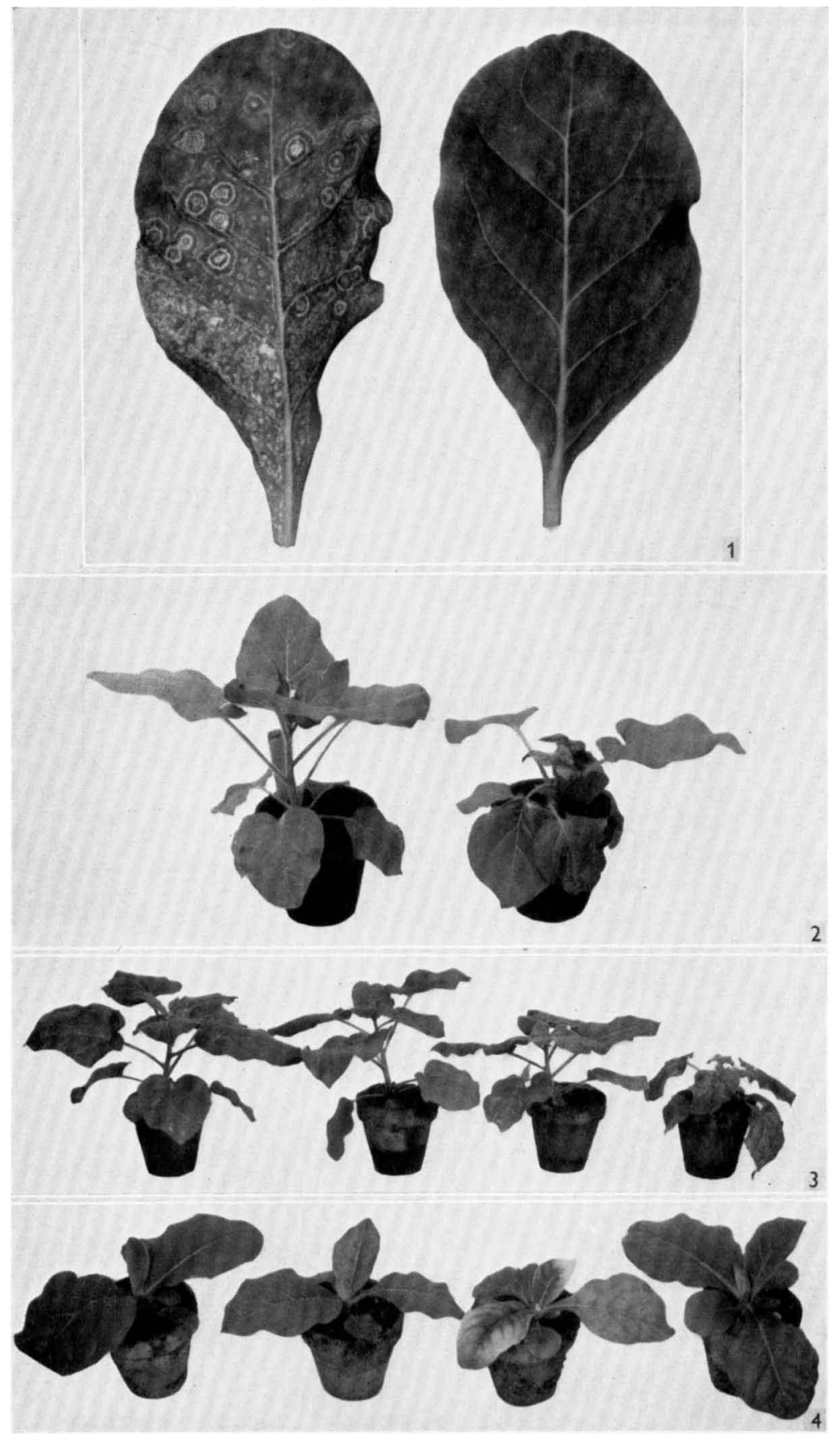

R. F. F. Matthews-Chemotherapy and piant viruses. Piate 1 